DOI: 10.46340/ephd.2021.7.3.6

Serhii Humennyi

ORCID ID: https://orcid.org/0000-0001-7168-8453

Taras Shevchenko National University of Kyiv, Ukraine

\title{
ANTI-ESPIONAGE ACTIVITIES \\ AND COUNTERACTION TO ILLEGAL MIGRATION \\ AT THE BORDER BETWEEN THE USSR \\ AND THE REPUBLIC OF POLAND IN 1929-1933
}

\author{
Сергій Гуменний \\ Київський національний університет імені Тараса Шевченка, Україна
}

\section{АНТИШПИГУНСЬКА ДІЯЛЬНІСТЬ ТА ПРОТИДІЯ НЕЛЕГАЛЬНІЙ МІГРАЦІЇ НА КОРДОНІ МІЖ СРСР І РЕСПУБЛІКОЮ ПОЛЬЩА У 1929-1933 рp.}

The purpose of the article is to analyze anti-espionage activities and violations of the state border regime by the authorized services of the Republic of Poland (Second Polish Republic) or the USSR, in the context of illegal migration in the border territories, during 1929-1933, for information purposes, the intelligence of Polish or USSR, or harmful action on the neighboring state. The proposed research examines, probably for the first time, the relationship between the state border protection and the targeted sabotage and intelligence activities of the Soviet side in the territory of the Republic of Poland during the accelerated collectivization, peasant uprisings and the Holodomor of 1932-1933. Analyzing the surge in activity of illegal migration processes on the Polish-Soviet border and the growing opposition from their border structures, we observe the ambivalence of the position of both countries, since the special services of Poland and the USSR, while raising the protection of the border, purposefully kept the illegal migration for the purpose of their own sabotage, reconnaissance and recruiting activities in the territory of the enemy. The struggle of the Ukrainian peasantry with collectivization, massive attempts to escape abroad from the repression and the Holodomor of 1932-1933 intensified the Soviet activity to build an intelligence network in the eastern provinces of the Republic of Poland, effectively neutralizing the polish forces in the neighboring country. Accordingly, further study of the cause-and-effect complex of illegal migration on the Polish-Soviet border in the 1920s-1930s, as a method of illegal entry into the territory of a neighboring state to carry out intelligence activities and create situations aimed at destabilization in the region, remains a relevant subject of further historical studies.

Keywords: intelligence, illegal migration, USSR, Poland, Soviet-Polish border, State Political Administration (GPU), Border Protection Corps (KOP).

Вивчення антиміграційної діяльності Корпусу охорони прикордоння (КОП) Республіки Польща та прикордонників УСРР (які були частиною єдиної радянської структури) у 1929-1933 рр., тобто в часі активного селянського опору колективізації і безпосередньо в період Голодомору 19321933 рр., постає важливим питанням для української та світової історичної науки. Територіальними рамками опрацьованої у статті проблеми слугуватимуть землі сучасних Житомирської та Хмельницької областей (утворені пізніше досліджуваних подій - у 1937 р.) України і Берестейської, Мінської областей Республіки Білорусь, а зокрема, існуючих з 1923 по 1930 р. Кам'янецької, Проскурівської, Шепетівської, Житомирської, Коростенської, Мозирської, Слуцької та Мінської округ з боку СРСР та прикордонні землі Тарнопольського і Волинського воєводств міжвоєнної Польщі (тепер Тернопільська й Рівненська області, Україна).

Сучасна історіографія дотична до незаконних міграційних процесів на «ризькому» кордоні (які фактично завжди існували пліч-о-пліч із шпигунською активністю), обмежується фундаментальними 
працями таких закордонних науковців: Тимоті Снайдера ${ }^{1}$, Генрика Домінічака, Марека Яблоновського, Артура Очала ${ }^{2}$, Криштофа Данілевіча ${ }^{3}$ та їх українських колег Миколи Кабачинського, Олександра Соловея ${ }^{4} .3$ огляду на обмеженість опрацьованого матеріалу, питання нелегальних мігрантів, які намагалися потрапити в Другу Річ Посполиту з території УСРР, факти розвідувально-диверсійної роботи на терені прикордоння досі залишаються малодослідженими. Компенсувати такий стан наукової розробки питання можна шляхом залучення неопублікованих джерел, що зберігаються в архівах Республіки Польща (Центральний військовий архів (CAW), Архів нових актів (AAN) у Варшаві) та України - Києва (ЦДАГО України), Житомира (ДАЖО) і Тернополя (ДАТО). Дослідження проведені у цих установах частково виконані в рамках «Dr. Ivan Iwanciw and Dr. Myroslawa Mysko-Iwanciw Scholarly Exchanges Grant» Канадського інституту українських студій (КІУС).

Метою статті є дослідження протидії уповноважених органів Польщі або СРСР порушенню режиму державного кордону, впродовж 1929-1933 рр., задля отримання, радянською чи польською стороною, інформації розвідувального характеру або здійснення шкідливих для сусідньої держави дій. Предметом дослідження, виступають факти боротьби із незаконним проникненням на територію II Речі Посполитої чи СРСР з метою отримання необхідної радянській або польській стороні інформації.

Описуючи історичне тло на якому відбувалися нелегальні міграційні процеси (особистий та колективний незаконний перетин кордону, контрабандні товарні відносини) зауважимо, що їх активізацію спричинила суцільна колективізація в УСРР, темпи якої зростали у геометричній прогресії 5 . Статистика наявна у архівних джерелах свідчить, що якщо станом на 1 січня 1930 р. в УСРР показники колективізації охоплювали близько 16\% селянських господарств, то 1 березня 1930 р. до об'єднаних зараховували уже 64\% господарств ${ }^{6}$. Як закономірна реакція, в лютому березні 1930 р. у прикордонних районах України селянський опір набирає рис повстання (або «волинок», як часто іменують ці події у документах) $)^{7}$. Виступи селян здебільшого закінчувалися розгоном повсталими радянських органів влади в районних центрах, розгромом колективних господарств на місцях. Дії жителів прикордоння були розраховані швидше на досягнення міжнародного розголосу (через демонстрування опозиційності діям радянської влади в зоні візуальної досяжності державного кордону), аніж на відкрите збройне протистояння більшовикам. У разі неефективності згаданих заходів або збройного переслідування з боку представників радянської влади, все більше селян декларували намір або здійснювали перехід кордону на польський бік. Наведемо промовистий приклад: 22 березня 1930 р. із села Соломна, Шепетівської округи, до кордону прямувала ціла церковна хода із хоругвами, а 28 березня в Польщу намагалися перейти, за даними історика Тимоті Снайдера, майже дві тисячі жителів села Печиводи, на чолі яких прямувала стара жінка із чорною хусткою на палиці ${ }^{8}$. Опозиційність колективізаційній політиці спостерігалася вздовж цілого українського відрізку польсько-радянського кордону та охоплювала місцевих жителів різних національностей, наприклад, 4 грудня 1929 р., із села Чорнокизинці Орининського р-ну Кам’янецької округи (тепер Кам'янець-Подільський р-н Хмельницької обл.), через «збручанський кордон», втекло до Польщі п’ять родин: по одній - польській та єврейській і три українські'.

Взявши до уваги факт наростання втеч із «країни Рад», зауважимо, що в часи розквіту i згортання НЕПу (1921-1929рр.) про нелегальну міграцію замислювалися жителі переважно

\footnotetext{
${ }^{1}$ Snyder, T. (2008). Tajna wojna: Henryk Jozewski i polsko-sowiecka rozgrywka o Ukrainȩ. Krakỏw: Wydawnictwo Znak, 134.

${ }^{2}$ Ochał, A., Ruczyński, M., Skubisz, P. (2018). U polskich stali granic. W 90 rocznice powstania Korpusu Ochrony Pogranicza. Szczecin-Warszawa, 118.

${ }^{3}$ Danielewicz, K. (2017). Lwowska Ekspozytura wywiadu. Działalność Ekspozytury nr 5 SG we Lwowie w latach 1921-1939. Toruń: Wydawnictwo Adam Marszałek, 265.

${ }^{4}$ Соловей, О. (2017). Міграџійні процеси на Волині у міжвоєнні роки (1918-1939): украӥнський вимір.

Хмельницький: Цюпак, 5.

${ }^{5}$ Подкур, Р., Васильєв, В., Кравченко, П., Петренко, В. (2013). Настрої та поведінка населення Поділля в умовах сталінської революиії «згори» 1928-1940. Київ: Інститут історії України НАН України, 16.

${ }^{6}$ Центральний державний архів громадських об’єднань України м. Київ (ЦДАГО України), ф. 1, on. 20, спр. 3153, арк. 68.

7 Літопис Волині (1955), 3, 82-85.

${ }^{8}$ Snyder, T. (2008). Tajna wojna: Henryk Józewski i polsko-sowiecka rozgrywka o Ukrainę. Krakỏw: Wydawnictwo Znak, 134.

${ }^{9}$ ЦДАГО України, ф. 1, on. 20, сnр. 2930, арк. 44.
} 
польської частини Волині й Галичини гнані національно-політичними переслідуваннями та безробіттям. Згідно даних по Коростенському окрузі УСРР у 1925 р. кордон із Польщі до УСРР перейшли 7 осіб, у 1927 - 6, 1928 - 2, а з початку 1929 р., у зв’язку з світовою економічною кризою, 11 осіб, записаних «хліборобами» та «робітниками»․ Натомість, за перше півріччя 1931 р., в Білоруській СРР прикордонники затримали на польському кордоні 1405 осіб, що відносилися до «куркулів», радянських або польських дезертирів, «перебіжчиків», які намагалися проникнути в СРСР. При цьому із 171-го «куркуля» 111 було затримано на кордоні при спробі втечі з СРСР, i лише 8 - намагалися повернутися ${ }^{2}$. В умовах синхронного розгортання колективізації і масових репресій посилюються пропольські настрої у радянському прикордонні - в селі Брониця Городницького р-ну (тепер Новоград-Волинського р-ну Житомирської обл.) на недобудованому будинку школи з'явився напис «Здесь будет польський штаб. Долой Соввласть. Да здравствует Польша» ${ }^{3}$. Також у розташованому, недалеко від кордону, Мархлевському польському національному районі (тепер територія Житомирщини), згідно даних британської історикині Кейт Браун, після антирадянських заворушень та тимчасового послаблення владного адміністративного тиску лише 7\% селянських господарств входили до колгоспів ${ }^{4}$.

3 іншого боку кордону, польська влада, з огляду на необхідність утримання добросусідських відносин з СРСР, власні економічні проблеми і соціально-політичну вибуховість «біженців», намагалася максимально зменшити їх прибуття на свою територію. В рамках цієї політики Львівська розвідувальна експозитура ІІ Відділу Головного штабу (SG) у 1930 р. спільно з польськими прикордонниками звинувачує у шпигунстві 74 особи із числа нелегальних мігрантів ${ }^{5}$. Хто із цих людей справді виконував розвідувальні завдання радянської сторони, а хто тікав від більшовицьких репресій та колективізації, виявити сьогодні вкрай важко. Документи як польської так і радянської сторони вкрай тенденційні та потребують скрупульозної верифікації, оскільки створені представниками державних структур, проте вони залишаються чи не єдиним джерелом (поряд із газетними публікаціями того часу), що висвітлює явище нелегальної міграції через «збручанський» кордон ${ }^{6}$.

Розглянемо кілька прикладів польської та радянської боротьби із шпигунською діяльністю коротко означивши інституції що нею займалися. У Республіці Польща з 1924 р. охорону кордону та прилеглих територій здійснювала воєнізована формація - Корпус охорони прикордоння (КОП), створена як відповідь на активізацію радянських диверсантів та агітаторів згідно програми «активної розвідки» (провадилася під керівництвом Розвідувального управління Штабу Робітничо-селянської Червоної Армії, далі - Розвідупру $)^{7} .15$ липня 1929 р. КОП отримала нову організацію розвідувальної служби, яка відтоді складалася з незалежних референтур (samodzielny referat) розвідки при керівництві КОП. В 1933 р. уся польська розвідувальна служба східного напряму перейшла під керівництво Розвідувального штабу (Szefostwo Wywiadu) КОП, що відповідав за експозитури II Відділення Головного штабу № 1 у Вільнюсі та № 5 у Львові, їх розвідувальні відділення Натомість, у радянській державі 27 вересня 1922 р. Рада Праці і оборони (РПО) передала охорону кордону відділу Державного Політичного Управління (ДПУ), створивши Окремий прикордонний

\footnotetext{
${ }^{1}$ Соловей, О. (2017) Міграџійні процеси на Волині у міжвоєнні роки, (1918-1939): украӥнський вимір.

Хмельницький: Цюпак, 89.

2 Дюллен, С. (2014). Уплотнение границ. К истокам советской политики. 1920-1940-е. Москва: Новое литературное обозрение, 143.

3 Державний архів Житомирської області (ДАЖО), $\phi$. П-132, on. 1, сnр. 55, арк. 13.

${ }^{4}$ Brown, K. (2005). A Biography of No Place. From Ethnic Borderland to Soviet Heartland. Cambridge, MA; London: Harvard University Press, 109-110.

${ }^{5}$ Centralne Archiwum Wojskowe (CAW). Wykaz osób oskarżonych o szpiegostwo na terenie Ekspozytury Lwowskiej w 1930 r. Oddział II SG, sygn. I.303.4.6998.

${ }^{6}$ Гуменний, С. (2019). Нелегальні міграції на кордоні між Республікою Польща та УСРР напередодні та під час Голодомору 1932-1933 рр., Вісник Київського національного університету імені Тараса Шевченка. Історія. Київ, 1 (140), 18-23.

${ }^{7}$ Humennyi, S. (2019). «Płonąca granica». Działalność szpiegowska w kontekście nielegalnych migracji na wschodniej granicy II Rzeczypospolitej (na przykładzie województwa tarnopolskiego). Pamięć i Sprawiedliwość. Pismo naukowe poświęcone historii najnowszej. Warszawa: Instytut Pamięci Narodowej - Komisja Ścigania Zbrodni przeciwko Narodowi Polskiemu, 33, 331; Воронов, В. (2018). Рассекречено. Правда об острых эпизодах советской эпохи. Москва: Алгоритм, 13.

${ }^{8}$ Ochał, A., Ruczyński, M., Skubisz, P. (2018). U polskich stali granic. W 90 rocznice powstania Korpusu Ochrony Pogranicza. Szczecin-Warszawa, 17-35.
} 
корпус, з 1926 р. керований Головним управлінням прикордонної охорони (ГУПО) ${ }^{1}$. У 1929 р. чисельність радянських прикордонних військ збільшилася у півтора раза, через «активізацією ворожої розвідки та провокації на кордоні» ${ }^{2}$. Для посилення замкнутості кордону, у квітні 1930 р. прийнято постанову «Про прикордонну смугу», в грудні 1930 р. - «Про політичне та господарське становище прикордонних районів УРСР», а з 1932 р. небо над кордоном розпочала патрулювати авіація ${ }^{3}$. Також радянськими прикордонниками, із місцевого населення, створювалися спеціальні «бригади сприяння» (згідно «Інструкції про порядок залучення населення прикордонної смуги до охорони кордону СРСР» від 9 травня 1931 р.), що мали спостерігати за появою в прикордонні невідомих осіб та підозрілими змінами на території сусідніх держав ${ }^{4}$.

Із подібної активізації розвідувальних заходів на державній межі (безпрецедентних 3 часів створення самого польсько-радянського кордону у 1921-1923 рр.), ставали зрозумілими наміри максимального обмеження проникності кордону для мігрантів. Посилення закритості кордону (яке все ж зберігало традиційні «вікна»- місцевості де нелегальний перехід через кордон або контрабанда відбувалися під патронатом польської або радянської сторони, як наприклад, в урочищі Черепки між Дорогощею та Острогом) співпало з часом активізації селянського опору колективізації та зростання спроб втечі від державної розправи за кордон 5 . Загальну ситуацію у прикордонні погіршувало і те, що 1928 р. в Україні стався великий неврожай, який загрожував голодом ${ }^{6}$. Уряд Республіки Польща побоюючись соціального вибуху у 1929 р., через той таки недорід і наслідки економічної кризи, закуповує імпортне зерно яке знижує ціни на збіжжя всередині країни тим самим розорюючи приватні господарства Волині ${ }^{7} .3$ огляду на це, бунтівні жителі УСРР, що тікали через кордон до Польщі також потрапляли у зону соціальної напруги невдоволеного політикою Варшави місцевого населення Волині і Галичини. Цілком очевидно, що толерування масовості таких міграцій було вкрай невигідне для Другої Речі Посполитої як з точки зору внутрішньої безпеки, так і задля уникнення ескалації у відносинах із СРСР.

І все ж деякий відсоток нелегальних мігрантів у 1930-х рр. стає життєво необхідним для існування польської розвідки в умовах максимальної закритості радянського кордону та ефективної (швидше за рахунок кількості аніж якості) боротьби спецслужб СРСР із польськими шпигунами. У період Голодомору 1932-1933 pр., на польсько-радянському кордоні спостерігається черговий значний сплеск нелегальної активності. До прикладу, за період з 24 червня по 24 липня 1933 р., на відтинку кордону, що підлягав розвідувальному відділу КОП № 10 у Тарнополі польськими прикордонниками було затримано 89 осіб за звинуваченнями у примусі до переходу державного кордону в напрямі СРСР чи Польщі, бродяжництві у прикордонні, контрабанді, підозрі у шпигунстві чи за опір прикордонникам КОП ${ }^{8}$. Особи, які перетинали польсько-радянський кордон становили важливу вербункові базу для польської розвідки, оскільки добре орієнтувалися у прикордонні, володіли місцевими діалектами, не виділялися одягом та звичками із середовища радянського населення. Співпраця з II Відділом Головного штабу (SG) Другої Речі Посполитої була переважно взаємовигідною і надавала втікачу із СРСР можливість залишитися на проживання в Польщі. У 19311933 рр. на відрізку кордону чотирьох розвідувальних відділів (Placówek Wywiadowczych) КОПу у Рокитному, Рівному, Тарнополі та Чорткові (підлягали Львівській розвідувальній експозитурі) було затримано 1894 біженці та дезертири. Із їх числа до розвідувальної діяльності на користь Польщі, за згодою, було залучено 162 особи‥ Нелегальні мігранти також виступали важливим джерелом

\footnotetext{
${ }^{1}$ Кабачинський, М. (2000). Історія кордонів та Прикордонних військ Украӥни: монографія. Хмельницький: Видавництво Хмельницької міської друкарні, 150-153.

${ }^{2}$ Буджук, В., Велидов, А. (1997). На страже границ отечества. Краткий очерк пограничных войск России,

Пограничник, 44-45

${ }^{3}$ Кабачинський, М. (2000). Історія кордонів та Прикордонних військ Украӥни, 155.

4 Лаврентьев, Ю. (1997). Привлечение населения приграничных районов к охране государственной границы СССР. Учебное пособие для курсантов пограничных военных училищ КГБ СССР. Москва, 17.

5 Руцький, М. (2003). Вертеп смерті. Літературно-документальне видання. Нетішин: Шепетівська міжрайонна друкарня, 22-24.

${ }^{6}$ Смолій, В.А. (ред.) (2006). Історія украӥнського селянства. Нариси в 2-х m, 2, 115.

${ }^{7}$ Соловей, О. (2017) Міграційні процеси на Волині у міжвоєнні роки, (1918-1939): украӥнський вимір.

Хмельницький: Цюпак, 89-104.

${ }^{8}$ CAW (1933). Oddziat II SG, sygn. I.303.4.7029 Wykaz sumaryczny osób przetrzymywanych na odcinku granicznym Placówki Wywiadowczej KOP nr 10 w Tarnopolu za okres 24 czerwiec do 24 lipiec 1933 r.

${ }^{9}$ CAW (1933). Oddziat II SG, sygn. I.303.4.7031 Wykaz uciekinierów i dezerterów z terenu ZSRR w okresie 1931 do 1 lipca 1933 r. nr. 1. dz. 2817 z. 19 października 1933 r.
} 
радянських документів для розвідувальних органів II Відділу Головного штабу - будь які бланки документів, які знаходилися в біженців негайно транспортувалися до Львова чи Варшави з метою їх вивчення та використання у розвідувальній діяльності ${ }^{1}$.

Алгоритм розвідувальної роботи можемо простежити усправі уродженця Городка на Хмельниччині, столяра Павла Рейтаровського (1894 р.н.). В липні 1932 р. його було завербовано i після коротких курсів, на початку серпня переправлено до Польщі. Згідно завдання агент (псевдонім «Чорний»), одразу після перетину кордону здався польській владі, як ревний католик, утікач від радянських репресій. Лише через деякий час, шпигун мав вийти із «сплячої фази» та розпочати збір інформації про дислокацію і діяльність, озброєння, маневри відділів КОП в районі Гусятина, Копичинець, Чорткова Тарнопольського воєводства. Паралельно Рейтаровський опрацьовував інформацію про ставлення місцевого населення до польської влади, взаємовідносини між ними. Зв'язок із своїми закордонними кураторами агент здійснював листами на адресу батька, в яких інформація розвідувального змісту писалася молоком поміж рядками чорнильного письма ${ }^{2}$. Конспірація «Чорного» виявилася вдалою - відділ розвідки КОП № 9 у Чорткові завербував його для виконання власних завдань на території УСРР. Одразу по перекиданню за кордон Павло з'являється до радянської комендатури, звідти скеровується до Проскурова де надає ДПУ описи будівель та особового складу компанії КОП «Гусятин», інформацію про залізничні станції гілки Гусятин Чортків, особисті дані працівників розвідувального відділення КОП № 9 у Чорткові. Натомість подвійному агенту, урядовцем ДПУ «Майоровим», було надано фальшиві розвіддані. 7 вересня 1932 р. «Чорний» знову переправляється до Польщі. Викрити подвійного шпигуна польським прикордонникам вдалося проаналізувавши його кореспонденцію - зміст висланого 31 серпня 1932 p., на конспіративну адресу до Чорткова, листа і його переказ самим Рейтаровським під час звітування, відрізнялися. Польські спецслужби припустили, що листи не були вислані особисто, у чому сам агент зізнався після двотижневих допитів, як врешті і про шпигунську діяльність на користь СРСР ${ }^{3}$.

У 1932 р., також сталася подія, що не мала аналогів 3 часів демаркації кордону - відбулися спроби проникнення невеликих груп повстанців із польської території на радянську для сприяння селянським заворушенням проти колективізації. Ці повстанські групи, на думку українського дослідника Олександра Соловея, використовували «тактику бджоли», що включала в себе діяльність малих мобільних груп, що з'являлися з-за кордону, робили диверсії і тікали назад. Проте така діяльність не увінчалася успіхом через зламаний колективізацією і голодом опір селянських мас, збільшення контингенту радянських прикордонників та війська ${ }^{4}$. Цифри знешкоджених прикордонними загонами «банд» незаконних мігрантів та шпигунів були ключовим аргументом для характеристики діяльність загону. Наприклад, 17-й Тимковицький прикордонний загін (с. Тимковичі Копильського р-ну Мінської обл., Республіка Білорусь), який охороняв білоруський відрізок польсько-радянського кордону, за період 1931-1935 pp. відзвітував про знищення «великих диверсійних банд Люцко, Дасюкевіча, контрреволюційної організації “Братство російської правди”, диверсійних груп Макарені і Ефімчіка, Янчука та ін. диверсійних груп братів Хвилястих, Жирук, Мірошевського, Дробені, Диби, банди Ковалені». За наведені успіхи загін нагородили орденом Червоного Прапора, як і 23-й Кам’янець-Подільський прикордонний загін

Поряд із цим, число шпигунських справ які проводила КОП становило половину загальнопольських: у 1928-1935 рр. на територіях 4-ох округів КОП польсько-радянського кордону викрито 2015 шпигунських афер, що вдвічі перевищувало чисельність таких на решті семи округах корпусу ${ }^{6}$. Але чи можна вважати усіх осіб звинувачених у шпигунстві дійсно винними? Швидше ні, оскільки інкримінація такого злочину як шпигунство дозволяла вивести нелегального мігранта

\footnotetext{
${ }^{1}$ Danielewicz, K. (2017). Lwowska Ekspozytura wywiadu. Działalność Ekspozytury nr 5 SG we Lwowie w latach 1921-1939. Toruń: Wydawnictwo Adam Marszałek, 318.

2 Там само, 373.

${ }^{3}$ CAW (1932). Oddziat II SG, sygn. I.303.4.7011 Doniesienie karne Placówki Wywiadowczej KOP nr 9 w Czortkowie w sprawie Pawła Rejtarowskiego, nr I.2208/tj.wyw. z. 19 września 1932 r.

${ }^{4}$ Соловей, О. (2015). Військово-політичні аспекти польсько-українських взаємин на території Волині у міжвоєнний період (1921-1939). Матеріали Всеукраїнської наукової конференцї «Війни і збройні конфлікти у Східній Свропі в XX-на початку ХХІ століть». Житомир: Полісся, 62.

5 Дюллен, С. (2014). Уплотнение грании. Москва: Новое литературное обозрение, 41.

${ }^{6}$ CAW (1936). Oddziat II SG, sygn. I.303.4.5082 Ogólne wiadomości o działalności wywiadów obcych w Polsce w latach 1929-1935.
} 
з орбіти можливостей місцевої української громади - єдиної сторони зацікавленої у допомозі біженцю. Протоколи засідань слідчої комісії СРСР і Польщі з питань переходу кордону польськими підданими містять твердження, що радянська сторона зацікавлена не випустити, а польська не впустити нелегальних мігрантів на «збручанському» кордоні ${ }^{1}$. Для цього і могли застосовуватися звинувачення у співпраці із розвідками інших країн. Крім того, поява нелегальних радянських мігрантів у Західній Волині під час світової кризи, яка боляче вразила польську економіку, створювала напругу на ринку праці аграрних працівників ${ }^{2}$.

Отже, нелегальні мігранти міжвоєнного двадцятиліття, від самої своєї появи на «ризькому» кордоні стали небажаним явищем для офіційної радянської та польської сторони. Боротьба із нелегальною міграцією та контрабандою через кордон ставала причиною розбудови прикордонної інфраструктури, збільшення контингенту прикордонників та військ у межових землях. Виникає питання, як взагалі могла існувати нелегальна міграція на одному із найзакритіших кордонів у переломний період 1929-1933 рр.? У відповідь наведемо висновки, що існувала переважно толерована польською чи радянською стороною нелегальна контрабандна діяльність і особиста міграція, яка активно використовувалася у власних економічних, розвідувальних або інформаційно-агітаційних цілях. Проти такої незаконної міграції боролися лише у випадку іï приналежності ворожій стороні і при цьому робилися спроби перевербування агента. Зовсім небажаною і навіть шкідливою, для радянської сторони виступала неконтрольована нею нелегальна міграція населення Волині та Поділля на територію Польщі у 1929-1933 рр. Такі емігранти загрожували витоком інформації про реалії колективізаційної, національної політики більшовиків в Україні, врешті у 1932-1933 рр. комуністична влада небезпідставно побоювалася, що біженці із СРСР повідомляють світу про Голодомор в радянській Україні ${ }^{3}$.

Інкримінування нелегальним мігрантам діяльності на користь іноземної розвідки, роздмухування шпигунської істерії, заходи щодо укріплення охорони державного кордону СРСР із «буржуазною Польщею» зробили нелегальний перетин кордону надзвичайно важким завданням. Із початку 1930-х рр. радянські органи держбезпеки взяли під свій контроль більшість контрабандних потоків на кордоні, залучаючи самих контрабандистів до власної агентурної сітки ${ }^{4}$. Нелегальний мігрант, який не співпрацював із ДПУ або хоча б не був завербований до такої співпраці, ставав радше винятком ніж правилом. Виходячи з таких міркувань та опираючись на власних інформаторів, прикордонники КОП, за наявності мінімальних передумов, звинувачували переважну більшість «збігців із СРСР» у співпраці з радянською розвідкою. Не рідкістю ставали екстрадиції біженців, одразу або після відбуття ув'язнення за співпрацю з іноземною розвідкою, назад до СРСР. Сцени таких передач часто ставали об'єктами критики західноукраїнської громадськості, оскільки радянські прикордонники нерідко одразу вбивали порушника режиму кордону ${ }^{5}$. Виходячи із юридичної точки зору, бійці КОП, в такій ситуації, діяли згідно власного статуту та польського законодавства, більше того, не поодинокими були випадки передачі польськими прикордонниками нелегального мігранта на утримання місцевій українській громаді або переправлення його через кордон, уже як власного резидента.

Підбиваючи підсумки, слід відзначити, що масовий сплеск активності нелегальних міграційних процесів на польсько-радянському кордоні активізував протидію цьому явищу з боку прикордонних структур Республіки Польща та СРСР. Однак, ці ж самі структури цілеспрямовано зберігали незаконну, переважно контрабандну, активність у прикордонні задля власної диверсійно-розвідувальної діяльності на території противника. Важливою складовою роботи прикордонних і безпекових відомств Польщі та СРСР цього періоду стає вербування власних

\footnotetext{
1 Державний архів Тернопільської області (ДАТО), . 2, on. 2, сnр. 158, арк. 8.

${ }^{2}$ Михалюк, М. (2011). Економічна криза 1929-1933-х рр. у фейлетонах Романа Купчинського (за матеріалами газети «Діло»). Наукові записки, 3(36). Львів: Українська академія друкарства, 152-161.

${ }^{3}$ Humennyi, S. (2019). «Płonąca granica». Działalność szpiegowska w kontekście nielegalnych migracji na wschodniej granicy II Rzeczypospolitej (na przykładzie województwa tarnopolskiego), Pamięć i Sprawiedliwość. Pismo naukowe poświęcone historii najnowszej, 33, 339; Дюллен, С. (2014). Уплотнение грании. Москва: Новое литературное обозрение, 96-97, 134.

${ }^{4}$ Феденев, Д. (1925). Борьба с контрабандой в СССР. Контрабанда и борьба с ней: по материалам Главного таможенного управления. Москва: РИО НКВТ, 116-207.

${ }_{5}^{5}$ Гуменний, С. (2019). Нелегальні міграції на кордоні між Республікою Польща та УСРР напередодні та під час Голодомору 1932-1933рр., Вісник Київського начіонального університету імені Тараса Шевченка. Історія. Київ, 1 (140), 20.
} 
агентів-інформаторів, викриття подібної діяльності іншої сторони, дезінформування та перевербування. Як не парадоксально, але боротьба українського селянства із колективізацією, масові спроби втечі за кордон від більшовицького переслідування та голоду, дозволили радянській стороні активізувати свою діяльність із розбудови розвідувально-інформаторської сітки у східних воєводствах Республіки Польща. В силу можливостей тоталітарної держави у застосуванні адміністративного ресурсу, масовості міграційних процесів та закритості державного кордону, спеціальним службам СРСР вдалося вести ефективну розвідувальну діяльність на польському напрямі частково нейтралізувавши агентурні сили сусідньої країни. 3'ясування причин і перебігу цих подій, подальше вивчення нелегальних міграцій на польсько-радянському кордоні у 20-30-ті рр. XX ст., як методу незаконного проникнення на територію сусідньої держави для здійснення розвідувальних заходів та створення ситуацій спрямованих на дестабілізацію у регіоні, залишається актуальною темою подальших історичних студій.

\section{References:}

1. Brown, K. (2005). A Biography of No Place. From Ethnic Borderland to Soviet Heartland. Cambridge, MA; London: Harvard University Press. [in English].

2. Budzhuk, V., Velidov, A. (1997). Na strazhe granic Otechestva. Kratkij ocherk istorii pogranichnyh vojsk Rossii [On guard of the borders of the Fatherland. A brief sketch of the history of Russia's border troops]. Pogranichnik [Border guard: magazine]. Moscow: Granica [in Russian].

3. Centralne Archiwum Wojskowe [Central Military Archives of the Republic of Poland]. Oddziat II SG, sygn. I.303.4.7029, I.303.4.703, I.303.4.7011, I.303.4.5082. [in Polish].

4. Danielewicz, K. (2017). Lwowska ekspozytura wywiadu: działalność ekspozytury nr 5 SG we Lwowie w latach 1921-1939 [Lviv branch of the intelligence: activity of branch no. 5 of the Border Guard in Lviv in the years 19211939]. Torun: Wydawnictwo Adam Marszałek. [in Polish].

5. Derzhavnyi arkhiv Ternopilskoi oblasti [State Archives of Ternopil Oblast], f. 2, op. 2, spr. 158, ark. 8. [in Polish].

6. Derzhavnyi arkhiv Zhytomyrskoi oblasti [State Archives of Zhytomyr Oblast], f. P-132, op. 1, spr. 55, ark. 13. [in Russian].

7. Dyullen, S. (2014). Uplotnenie granic. K istokam sovetskoj politiki. 1920-1940-e [Consolidation of borders. To the origins of Soviet politics. 1920-1940s]. Moscow: Novoe literaturnoe obozrenie. [in Russian].

8. Fedenev, D. (1925). Bor'ba s kontrabandoj v SSSR [The fight against smuggling in the USSR]. Kontrabanda $i$ bor'ba s nej: po materialam Glavnogo tamozhennogo upravlenija [Smuggling and the fight against it: based on the materials of the Main Customs Directorate]. Moscow: RIO NKVT. [in Russian].

9. Humennyi, S. (2019). «Płonąca granica». Działalność szpiegowska w kontekście nielegalnych migracji na wschodniej granicy II Rzeczypospolitej (na przykładzie województwa tarnopolskiego) [«The border on fire». Spying, in the context of illegal migration at the eastern border II Republic (as an example Ternopil region).]. Pamięć i Sprawiedliwość. Pismo naukowe poświęcone historii najnowszej [Remembrance and Justice]. Warszawa: Instytut Pamięci Narodowej - Komisja Ścigania Zbrodni przeciwko Narodowi Polskiemu. [in Polish].

10. Humennyi, S. (2019). Nelehalni mihratsii na kordoni mizh Respublikoiu Polshcha ta USRR naperedodni ta pid chas Holodomoru 1932-1933 rr. [Illegal migration on the border between the Republic of Poland and the USSR before and during The Holodomor of 1932-1933]. Visnyk Kyivskoho natsionalnoho universytetu imeni Tarasa Shevchenka. Istoriia [Bulletin of Taras Shevchenko National University of Kyiv. History], 1 (140), 18-23. [in Ukrainian].

11. Kabachynskyj, M. (2000). Istoriia kordoniv ta Prykordonnykh viisk Ukrainy [History of borders and Border Troops of Ukraine]. Khmelnytskyi. [in Ukrainian].

12. Lavrentev, Yu. (1977). Privlechenie naselenija prigranichnyh rajonov k ohrane gosudarstvennoj granicy SSSR. Uchebnoe posobie dlja kursantov pogranichnyh voennyh uchilishh KGB SSSR [Involvement of the population of border areas in the protection of the state border of the USSR. A textbook for cadets of the border military schools of the KGB of the USSR.]. Moscow. [in Russian].

13. Litopys Volyni [Chronicle of Volyn]. (1955). 3, 82-85. [in Ukrainian].

14. Mykhaliuk, M. (2011). Ekonomichna kryza 1929-1933kh rr. u feiletonakh Romana Kupchynskoho (za materialamy hazety «Dilo») [The economic crisis of 1929-1933 in Roman Kupchynsky's feuilletons (based on the materials of the Dilo newspaper)]. Naukovi zapysky [Scientific Notes]. Ukrainska akademiia drukarstva, 3 (36), 152-161. [in Ukrainian].

15. Ochał, A., Ruczyński, M., Skubisz, P. (2018). U polskich stali granic. W 90 rocznice powstania Korpusu Ochrony Pogranicza [At Polish borders. In the 90 anniversary of the Border Protection Corps]. Szczecin-Warszawa. [in Polish].

16. Rutskyi, M. (2003). Vertep smerti. Literaturno-dokumealne vydannia [Nativity scene of death. Literary and documentary edition]. Netishyn: Shepetivska mizhrajonna drukarnia. [in Ukrainian]. 
17. Smolii, V. (ed.). (2006). Istoriia ukrainskoho selianstva. Narysy u 2-kh tomakh [History of the Ukrainian peasantry. Essays in 2 volumes]. Kyiv, 2. [in Ukrainian].

18. Snyder T. (2008). Tajna wojna: Henryk Józewski i polsko-sowiecka rozgrywka o Ukrainę [Sketches from a Secret War: A Polish Artist's Mission to Liberate Soviet Ukraine]. Krakow: Znak. [in Polish].

19. Solovei, O. (2015). Viiskovo politychni aspekty polsko ukrainskykh vzaiemyn na terytorii Volyni u mizhvoiennyi period (1921-1939) [Military-political aspects of Polish-Ukrainian relations on the territory of Volhynia in the interwar period (1921-1939)]. Materialy Vseukrainskoi naukovoi konferentsii «Viiny i zbroini konflikty u Skhidnii Yevropi v XX-na pochatku XXI stolit» [Proceedings of the All-Ukrainian Scientific Conference «Wars and Armed Conflicts in Eastern Europe in the XX-early XXI centuries»]. Zhytomyr: Polissia. [in Ukrainian].

20. Solovei, O. (2017). Mihratsiini protsesy na Volyni u mizhvoienni roky (1918-1939): ukrainskyi vymir [Migration processes in Volyn in the interwar years (1918-1939): Ukrainian dimension]. Khmelnytskyj. [in Ukrainian].

21. Tsentralnyi derzhavnyi arkhiv hromadskykh objednan Ukrainy [Central State Archive of Supreme Bodies of Power and Government of Ukraine], f. 1, op. 20, spr. 2930, 3153. [in Russian].

22. Voronov, V. (2018). Rassekrecheno. Pravda ob ostryh epizodah sovetskoj epohi [Declassified. The truth about the acute episodes of the Soviet era]. Moscow: Algoritm. [in Russian]. 